\title{
PENINGKATAN HASIL BELAJAR SISWA DALAM PARAFRASE PUISI MELALUI PENDEKAT COOPERATIF LEARNING PADA SISWA KELAS VI A SDN 105288 SEI ROTAN
}

\author{
Gusni Rosdiani Harahap
}

Surel: gusni.rosdiani@gmail.com

\begin{abstract}
ABSTRAK
Penelitian ini bertujuan untuk meningkatkan hasil belajar siswa dalam parafrase puisi melalui pendekatan kooperatif learning di kelas VI A SDN 105288 Sei Rotan Kecamatan Percut Sei Tuan Kabupaten Deli Serdang. Metode penelitian ini adalah Penelitian Tindakan Kelas (PTK) yaitu berkolaborasi dengan teman sejawat. Hasil yang diperoleh yaitu peningkatan kemampuan parafrase puisi siswa yang sangat optimal ditinjau dari hasil evaluasi pada setiap akhir siklus. Siklus I nilai rata-rata siswa mencapai 68,59\%, siswa yang mencapai skor $>69 \%$ adalah 56,25\%. Sedangkan pada siklus II nilai rata-rata siswa mencapai $76,09 \%$, siswa yang mencapai skor $>69 \%$ adalah $78,37 \%$. Dari data yang telah dipaparkan tersebut dapat dilihat bahwa terjadi peningkatan yang sangat baik atau memuaskan.
\end{abstract}

Kata Kunci: Cooperatif Learning, bahasa Indonesia, Parafrase

\section{PENDAHULUAN}

Pengajaran Bahasa dan Sastra khususnya parafrase puisi adalah pengajaran yang mengajak anak untuk membuat sebuah puisi ke dalam bentuk prosa. Pada pelajaran ini anak dituntut untuk dapat memahami puisi agar dapat merubahnya dalam bentuk prosa. Dari pengalaman peneliti sebagai pendidik (guru kelas VI) merasakan ada beberapa masalah yang sangat mendasar pada siswa kelas VI dalam materi sastra,khususnya parafrase puisi. Sastra merupakan sesuatu yang asing bagi siswa, sehingga pengetahuan siswa sangat minim sekali tentang apresiasi sastra. Karya sastra dibangun oleh dua unsur yaitu unsur instrinsik dan unsur ekstrinsik. Unsur ekstrinsik merupakan unsur yang membangun karya sastra dari luar. Sedangkan unsur instrinsik merupakan unsur yang membangun karya sastra dari dalam sastra itu sendiri.

Materi atau pokok bahasan tentang parafrase puisi merupakan masalah yang sulit terpecahkan dalam proses pembelajaran di kelas VI SDN 105288 Sei Rotan. Materi apresiasi sastra merupakan pelajaran yang sering dianggap terlalu sulit bagi siswa, sehingga siswa kurang termotivasi dalam mempelajarinya. Dari hasil formatif (ulangan harian) yang dilakukan oleh guru/peneliti dari 32 siswa hanya 5 orang siswa saja yang mencapai KKM (Kreteria ketuntasan Minimal) selebihnya masih dibawa KKM (29 siswa). Hal inilah yang membuat guru/peneliti melakukan perubahan pendekatan dalam membelajarkan parafrase puisi 
yang selama ini pembelajaran dilakukan secara konvensional.

Pembelajaran sastra di sekolah terutama untuk anak-anak, dapat dikatakan belum maksimal. Masih banyak guru bahasa dan sastra Indonesia yang merasa kesulitan jika harus berhadapan dengan kompetensi dasar bahasa dan sastra Indonesia. Guru banyak mengalami persoalanpersoalan dalam menyampaikan materi pembelajaran, media pembelajaran, model pembelajaran guru yang tepat sasaran bahkan alat evaluasi yang sesuai. Meskipun tampaknya keadaan ini bersifat subjektif, namun banyak guru yang merasakan bahwa hal itu memang menjadi masalah bagi mereka. Sebagai dampaknya, maka guru akan mengajar hanya memenuhi kewajiban tanpa ada rasa menikmati karena memang kurang pemahaman mereka tentang strategi pembelajaran sastra yang efektif dan efesien. Sedangkan dampak yang ditimbulkan bagi anakanak adalah: (1) pembelajaran (2) kering (3) tidak menantang, akhirnya (4) tidak tertarik untuk belajar sastra. Padahal pembelajaran sastra bagi anak-anak adalah suatu aktifitas yang menyenangkan dan penuh tantangan asalkan gurunya mampu menyajikan penuh perasaan dan straregi yang inovatif.

Pengajaran materi parafrase puisi melalui pendekatan cooperatif learning diharapkan mampu meningkatkan hasil belajar siswa kelas VI A SDN 105288 Sei Rotan.
Masalah yang terdapat pada siswa dalam memparafrase puisi seperti : a. motivasi siswa agar menyenangi pembelajaran apresiasi sastra, khususnya pada materi parafrase puisi, b. memunculkan motivasi instrinsik untuk mempelajari materi yang disajikan, c. mengembangkan /mengggunakan pendekatan cooperatif learning dalm pembelajaran berbasis kelompok dalam proses pembelajaran parafrase puisi. Hal ini sejalan dengan tujuan dari pendekatan cooperatif learning, yaitu suatu modal pembelajaran yang saat ini banyak digunakan untuk mewujudkan kegiatan belajar mengajar yang saat ini banyak digunakan untuk mewujudkan kegiatan belajar mengajar yang berpusat pada siswa (student oriented), terutama untuk mengatasi permasalahan yang ditemukan guru dalam mengaktifkan siswa. Model pembelajaran ini telah terbukti dapat dipergunakan dalam berbagai mata pelajaran dan berbagai usia.

Ada banyak alasan mengapa kooperatif learning tersebut mampu memasuki "mainstream” (kelaziman) praktek pendidikan. Selain buktibukti nyata tentang keberhasilan pendekatan ini pada masa sekarang masyarakat pendidikan semakin menyadari pentingnya para siswa berlatih berpikir, memecahkan masalah, serta menggabungkan kemampuan dan keahlian. Walaupun memang pendekatan ini akan berjalan dengan baik di kelas yang 
kemampuannya merata, namun sebenarnya kelas dengan kemampuan siswa yang bervariasi lebih membutuhkan pendekatan ini. Karena dengan mencampurkan para siswa dengan kemampuan yang beragam tersebut, maka siswa yang kurang akan sangat terbantu dan termotivasi pada siswa yang lebih. Demikian juga siswa yang lebih akan semakin terasa pemahamannya.

Hal ini sejalan dengan tujuan dari pendekatan cooperatif learning, yaitu suatu modal pembelajaran yang saat ini banyak digunakan untuk mewujudkan kegiatan belajar mengajar yang saat ini banyak digunakan untuk mewujudkan kegiatan belajar mengajar yang berpusat pada siswa (student oriented), terutama untuk mengatasi permasalahan yang ditemukan guru dalam mengaktifkan siswa. Model pembelajaran ini telah terbukti dapat dipergunakan dalam berbagai mata pelajaran dan berbagai usia.

\section{METODE PENELITIAN}

Penelitian ini dilakukan atas dasar temuan pada saat melakukan observasi awal terhadap proses pembelajaran Bahasa Indonesia. Dari hasil observasi awal ditemukan, guru dalam mengajarkan materi parafrase puisi belum begitu optimal, baik dari segi isi, pendekatan pembelajaran, bahan ajar, dan media pembelajaran. Dalam upaya membantu guru memecahkan dan mengkaji setiap permasalahan yang muncul dilakukan sebuah kolaborasi dengan teman sejawat, sehingga metode penelitian yang dipilih adalah penelitian tindakan kelas (PTK). Penelitian ini dilaksanakan di kelas VI A SDN 105288 Sei Rotan Kecamatan Percut Sei Tuan Kabupaten Deli Serdang.

Instrumen dan Teknik Pengumpulan Data

Pada penelitian ini yang berperan sebagai sumber instrumen utama adalah peneliti sendiri dan dibantu oleh beberapa instrumen lain diantaranya: lembar tes tertulis, lembar observasi, catatan lapangan, lembar panduan wawancara. Secara lebih terinci teknik pengambilan data

\section{HASIL PENELITIAN Siklus I}

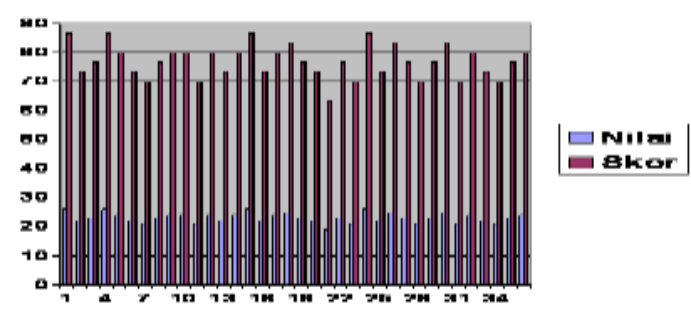

\section{Grafik Hasil Belajar Siklus I}

Dari grafik di atas dapat dilihat bahwa siswa yang telah berhasil menuntaskan pembelajaran sesuai dengan standar ketuntasan dalam penelitian ini hanya 18 orang atau 56,25\% dari jumlah keseluruhan subjek penelitian. Dan nilai rata-rata siswa secara klasikal yang diperoleh berdasarkan tes akhir tindakan pada siklus I adalah 68,59\%. Hal ini mengindikasikan bahwa hasil 
maksimal dari pembelajaran dan tes belum tercapai.

\section{Siklus 2}

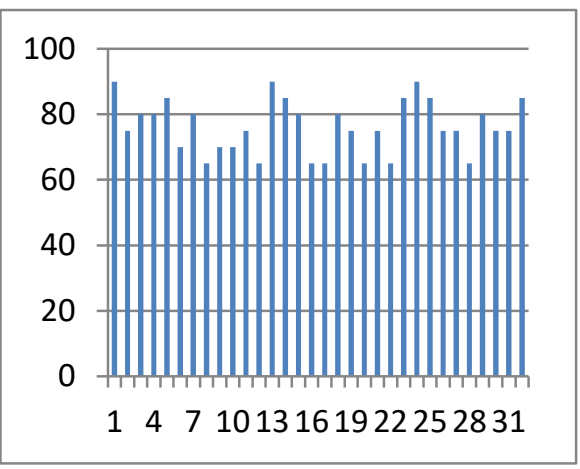

Grafik Hasil Belajar Siklus I

Evaluasi hasil akhir pembelajaran pada siklus II dalam bentuk tes yang dilakukan oleh peneliti yang berkolaborasi dengan observer dapat dijabarkan bahwa nilai rata-rata siswa secara klasikal adalah 76,09 serta yang memeperoleh nilai di atas KKM adalah 78,37\%. Pembelajaran dikatakan berhasil apabila memenuhi kriteria sukses. Sehubungan dengan bab tiga kriteria sukses yang digunakan adalah apabila nilai rata-rata tes siswa $\geq 69$ dan tuntas secara klasikal jika seluruh siswa $\geq 75 \%$ mencapai KKM. Berdasarkan data hasil tes siklus II dapat disimpulkan bahwa siswa (subjek penelitian) telah menyelesaikan proses pembelajaran dengan baik, dengan kata lain kemampuan Parafrase Puisi siswa dengan menggunakan pendekatan cooperatif learning meningkat dengan sangat baik.

\section{Pembahasan}

Pada bagian pembahasan ini akan diuraikan temuan penelitian yang telah dideskripsikan dan dianalisis sebelumnya oleh peneliti yang dibantu oleh kedua observer. Penerapan pendekatan Cooperatif Learning dapat digunakan untuk meningkatkan kemampuan Parafrase puisi. Sedangkan respon siswa terhadap pembelajaran dengan pendekatan Cooperatif Learning dan hasil belajar siswa pada siklus 1 dan siklus II digunakan sebagai alat untuk menguatkan dan membuktikan bahwa kemampuan analisis intrinsik karya sastra benar-benar meningkat sehingga dalam materi memparafrase puisi hasil belajar siswa juga meningkat dalam penelitian ini.

Dalam penelitian ini, guru yang sekaligus bertindak sebagai peneliti tidak mengalami kesulitan yang berarti dalam menjalankan proses pembelajaran dengan menggunakan pendekatan Cooperatif Learning. Hal ini dapat dilihat dari kemampuan guru/peneliti dalam menjalankan poin demi poin yang terdapat dalam format observsi kegiatan guru (lampiran 8a). Atau dengan kata lain guru/peneliti telah memenuhi keriteria indikator keberhasilan tindakan yang terdapat dalam penelitian ini.

Semua siswa yang menjadi subjek dalam penelitian ini menyatakan sangat senang, aktif, dan tekun melaksanakan tugas dalam proses pembelajaran dengan 
pendekatan Cooperatif Learning. Siswa juga mengemukakan bahwa lebih mudah memahami dan memecahkan masalah dalam materi pembelajaran dengan pendekatan Cooperatif Learning. Respon siswa yang positif ini, merupakan salah satu cara yang dapat digunakan untuk menciptakan kondisi pembelajaran dalam upaya meningkatkan kemampuan parafrase siswa. Serta dapat pula digunakan sebagai upaya siswa dalam memahami materi analisis unsur intrinsik sebuah puisi.

Peningkatan kemampuan parafrase puisi siswa kelas kelas VIA SDN 105288 Sei Rotan sangat optimal jika ditinjau dari hasil evaluasi pada setiap akhir siklus. Siklus I nilai rata-rata siswa mencapai $68,59 \%$, siswa yang mencapai skor $>69 \%$ adalah $56,25 \%$. Sedangkan pada siklus II nilai rata-rata siswa mencapai $76,09 \%$, siswa yang mencapai skor $>69 \%$ adalah $78,37 \%$. Dari data yang telah dipaparkan tersebut dapat dilihat bahwa terjadi peningkatan yang sangat baik atau memuaskan terhadap peningkatan hasil belajar siswa SDN 105288 Sei Rotan pada materi parafrase puisi. Hal ini senada dengan hasil penelitian yang ditemukan oleh peneliti lain sebelumnya dengan menggunakan pendekatan Cooperatif Learning pada pokok bahasan yang berbeda (penelitian yang relevan).

Tanggapan siswa tentang perasaan masing-masing individu dalam proses pembelajaran dapat dilihat dari ekspresi diri mulai dari senyuman (wajah ceria), keaktifannya dalam proses pembelajaran. Siswa mau bertanya jika ada sesuatu yang kurang dimengerti, dan siswa juga tidak segan-segan dalam memberikan pujian seperti bertepuk tangan jika jawaban rekannya benar, siswa terlibat secara aktif dalam bekerja sama dalam kelompok. Ekspresi diri dalam wujud perasaan senang siswa dalam mengikut proses pembelajaran ini merupakan hasil yang sangat positif dan menggembirakan, karena sudah menjadi rahasia umum bahwa mata pelajaran Bahasa Indonesia sulit untuk dikuasai, dipahami, dan permasalahan yang paling dominan adalah mata pelajaran ini dianggap gampang oleh siswa sehingga siswa sering terjebak.

Selain itu melalui proses pembelajaran dengan menggunakan pendekatan Cooperatif Learning ini, siswa mendapatkan kesempatan untuk mengekspresikan diri mengemukakan pendapat (ide-ide) yang ditemukan selama proses pembelajaran sehingga siswa dapat berpartisipasi dalam setiap diskusi di kelas. Sehingga pada akhirnya dapat menambah wawasan dan pengetahuan, serta siswa juga dapat mengetahui dan memahami bahwa masalah dalam karya sastra dapat dipecahkan dengan menggunakan berbagai macam pendekatan terutama dengan pendekatan Cooperatif Learning. Respon siswa yang sangat 
positif ini muncul bukan hanya karena tujuan utamanya adalah memecahkan masalah dan menemukan jawaban, akan tetapi lebih dari itu, yaitu menekankan kepada siswa bagaimana cara untuk sampai kepada suatu jawaban yang benar serta sempurna.

Dari pemaparan hasil temuan penelitian di atas dapat disimpulkan bahwa subjek penelitian (siswa) telah memenuhi keriteria ketuntasan belajar dalam penelitian ini. Siswa telah memperlihatkan respon-respon yang positif setelah kegiatan pembelajaran berlansung: (a) siswa mampu mengemukakan pendapat, mengkritisi, dan memberikan aplus terhadap pendapat yang dikemukakan oleh siswa lain; (b) siswa dapat mengubah puisi ke dalam bentuk prosa (parafrase) dengan baik; (c) Hasil belajar subjek penelitian (siswa) telah memenuhi keriteria ketuntasan belajar yang merujuk pada KKM yaitu: skor ketuntasan belajar itu $\geq 69$ dan yang memperoleh skor $\geq$ 69 harus $75 \%$ peserta (siswa). Siswa yang dianggap tuntas secara individu dalam proses pembelajaran apabila sudah mencapai skor $\geq 69$ dan tuntas secara klasikal apabila $\geq 75 \%$ dari jumlah keseluruhan siswa dalam satu kelas telah mencapai skor tersebut.

\section{KESIMPULAN}

Simpulan dari penelitian ini didasarkan pada hasil temuan penelitian dan analisis data yang telah dipaparkan di atas, maka dengan ini dapat disimpulkan bahwa, kemampuan analisis unsur intrinsik karya sastra siswa kelas $\mathrm{VI}^{\mathrm{A}} \mathrm{SDN}$ 105288 seperti: tema, amanat, nada (suasana puisi), rasa dalam puisi, citraan (pengimajian), dan diksi (pilihan kata) meningkat dengan sangat baik, sehingga kemampuan parafrase siswa meningkat pula. Hal ini dikuatkan oleh hasil belajar yang diperoleh siswa pada siklus I dan siklus II yang mengalami peningkatan dengan sangat memuaskan melalui pendekatan Cooperatif Learning.

Dengan menggunakan pendekatan Cooperatif Learning dalam proses pembelajaran dapat meningkatkan respon siswa terhadap proses belajar dalam mata pelajaran Bahasa Indonesia. Hal ini dapat dilihat dari hasil angket respon dan wawancara yang menunjukkan hasil sangat positif. Selain itu pembelajaran dengan pendekatan Cooperatif Learning dapat membuat suasana belajar lebih baik dan menyenangkan.

\section{DAFTAR RUJUKAN}

Ahman. 2000. Bimbingan

Perkembangan: Model

Bimbingan dan Konseling di

Sekolah Dasar, (Laporan Hasil Penelitian). Bandung: Jurnal Psikologi Paedagogia Volume I Desember 2009.

A.M, Sadirman. 2009. Interaksi dan Motivasi Belajar. Jakarta: Penerbit Raja Grafindo Persada. 
Asep, Herry Hermawan dkk. 2007. Teori Mengajar: Ilmu Pendidikan Teoritis: TPIP FIP - UPI Bandung Jilid 1.

Asep, Herry Hermawan dkk. 2007. Pengembangan Kurikulum dan Pengajaran. Jakarta: Pusat Penerbitan Universitas Terbuka.

Badan Standar Nasional Pendidikan (BSNP). 2006. Jakarta

Depdiknas. 2003. Pedoman Khusus Pengembangan Silabus dan Sistem Penelitian Mata Pelajaran Bahasa dan Sastra Indonesia. Digandakan oleh: Proyek Peningkatan Mutu.

Djamarah, dkk. 2006. Strategi Belajar Mengajar. Jakarta: Penerbit Rhineka Cipta.

Depdiknas. 2006. Panduan Penyusunan Kurikulum Sekolah: Jenjang Pendidikan Dasar dan Menengah. Badan Standar Nasional Pendidikan.

Hera, Lestari Mikarsa dkk. 2007. Pendidikan Anak SD. Jakarta: Pusat Penerbitan Universitas Terbuka.

Isjoni. 2009. Cooperative Learning. Mengembangkan Kemampuan Mengajar Kelompok. Bandung: Penerbit Alfabeta.

Kurniawan, Heru. 2009. Satra Anak Dalam Kajian Strukturalisme,
Sosiologi, Semiotika, Hingga Penulisan Kreatif. Jakarta: Penerbit Graha Ilmu.

Santosa, Puji dkk. 2007. Materi dan Pembelajaran bahasa Indonesia. Jakarta: pusat penerbitan Universitas Terbuka.

Sa'ud, Udun Syaefudin dkk. 2007. Pendidikan Dasar dan Menengah.Pendidikan Lintas Bidang. TPIP FIP - UPI. Jilid 3.

Slamento. 2008. Belajar dan Faktorfaktor yang Mempengaruhinya. Jakarta: Penerbit Rinneha.

Soedijarto. 2007. Pendidikan dan Sistem Pendidikan Nasional. Pendidikan Lintas Bidang. TPIP FIP UPI. Jilid 4.

Sri lengkawati, Nenden. 2007. Pendidikan Bahasa. Pendidikan Lintas Disiplin Ilmu: TPIP FIP UPI. Jilid 3.

Suciati, dkk. 2007. Belajar dan Pembelajaran 2. Jakarta: Pusat Penerbitan Universitas Terbuka.

Susilana, Rudi. 2007. Sumber Belajar. Ilmu Pendidikan Praktis. TPIP FIP - UPI. Jilid 2. 